\title{
A Literature Review on Consumer's Complaining Behavior and Dissatisfaction: Implication of Marketing Strategies with Special Reference to the Online Retail Sector
}

\author{
Komal \\ University School of Business, Chandigarh University, Mohali, India \\ Email: komaltomar789@gmail.com
}

How to cite this paper: Komal (2021). A Literature Review on Consumer's Complaining Behavior and Dissatisfaction: Implication of Marketing Strategies with Special Reference to the Online Retail Sector. Open Journal of Business and Management, 9, 496-511. https://doi.org/10.4236/ojbm.2021.92027

Received: January 5, 2021

Accepted: February 22, 2021

Published: February 25, 2021

Copyright $\odot 2021$ by author(s) and Scientific Research Publishing Inc. This work is licensed under the Creative Commons Attribution International License (CC BY 4.0).

http://creativecommons.org/licenses/by/4.0/ (c) (i) Open Access

\begin{abstract}
Customer complaint behavior (CCB) is defined as an action that is associated with the evaluation of the consumer experience with the consumption of the product. The product consumption outcome may be positive or negative depending upon the quality of the product and the needs of the consumer. The current research aims to contemplate online consumer behavior and its relationship with the online retail sector. It was found that by developing interactive platforms, the consumers can directly connect with the company and share their grievances and feedback with them. It will help the company to get understanding the needs and wants of the consumers and modify the product or service accordingly to meet their demands. It also includes adopting different marketing tools such as affiliate marketing, referral marketing, blogs, and social media marketing that are used by online retailers to improve consumer service levels.
\end{abstract}

\section{Keywords}

Consumer's Complaining Behavior, Online Retail Sector, Marketing Strategies, Affiliate Marketing, Referral Marketing

\section{Introduction}

\subsection{Research Background}

Customer complaint behavior (CCB) is referred to as the action that is taken by an individual after experiencing negative product consumption attributes. When a product is received by the consumer, it produces positive or negative outcomes 
depending upon the quality, price, and expectations of the consumers about the product. If the product meets the quality and expectations of the consumer, there are no complaints, but if the quality and expectations of the consumer are not met, it results in CCB (Alqahtani, 2011).

Dissatisfaction with the product may lead to altering outcomes because of the different nature of the consumers. Being dissatisfied with the product, the consumer may choose to make a private complaint to the company or altogether reject using the products of the company. Moreover, if the consumer is dissatisfied, he/she would not recommend the product to friends, family, or relatives resulting in loss of word of mouth publicity for the company. The consumer may also choose to complain about social media sites by posting negative comments or user experience regarding the consumption of the product. All these attributes negatively impact the association between consumers and retailers and weaken the bond of trust between them (Phau \& Sari, 2004).

Complainants are categorized into different types depending upon their response style to the issues with the products. It includes passive complainants that do not make any complaints against the retailer or company even if they are dissatisfied with the product. The second category is complainant of voicers that complain about the poor quality of the product and asks for replacement or readdress the issue with the retailer. The third type of complainant is irate that makes a direct complaint to the company and along with that provides negative comments and remarks about the product through word of mouth. It also includes posting negative comments on all social media platforms and switching providers to ensure that they do not receive poor quality products again. The fourth category of complainants is activists that complain to third party agencies so that the issue is readdressed and social change is initiated in the online retailing segment (Singh, 1990).

CCB is also associated with personality-based complaints as different consumers have different personalities and they react differently. For example, the consumers that have aggressive personalities are likely to voice against issues faced by them on receiving poor quality products. Aggressive personality consumers make complaints to the online retailer and complaint agency regarding the discrepancies in the product and the failure of their expectations. On the other hand, some consumers have less aggressive personalities. Such consumers do not express their discontent openly and prefer to make private complaints to the company. It includes privately boycotting the use of products and warning close associates, friends, and family against using the default company products (Meng, Wang, Peters, \& Lawson, 2010).

CCBs among different countries and communities are different. For example, consumers in Korea are more likely to make private complaints in comparison to open complaints. On the other hand, the consumers in the United States prefer to make public complaints in place of private complaints. The Mexican consumers are also found to be aggressive and complain more often as compared to 
Chinese consumers. Through the present paper, we aim to study the Consumer's Complaining Behaviour (CCB) and dissatisfaction and its implication of marketing strategies with special reference to the online retail sector. We also aim to contemplate online consumer behavior and their relationship with the online retail sector.

\subsection{Statement of the Problem}

Customer complaint behavior (CCB) is defined as an action that is associated with the evaluation of the consumer experience with the consumption of the product. The product consumption outcome may be positive or negative depending upon the quality of the product and the needs of the consumer. CCB includes the reaction of an individual regarding the purchase of a product and assessing the value of the product against its price. If the value of the product and the price of the product are aligned, there are no complaints by the consumers. However, if, the value and price of the product have differentiation and the quality of the product does not justify its price, there are complaints by the consumers (Tronvoll, 2007). Thus, it can be dissatisfaction of the consumer with the product either with quality or price or any other product feature leads to CCB. While focusing on the online retail segment, the consumer buy product without touching or trying them which often leads to dissatisfaction among the consumers as the purchase is made based on the image of the products. However, many times the image of the product is different from the actual product that is received by the consumer. The discrepancies in the online specified product image and feature and actual product crate discontent among the consumers. As a result, the dissatisfied consumer adopts complaint behavior and provides negative feedback for the product. The CCB could be reduced by providing quality post-purchase services. It includes addressing the needs and complaints of the consumer either by replacing the product with a better quality product or mending the product with the consumer. The provision of high-quality post-sales services will help to rebuild the trust of the consumer on the company and product and create long term associations with the brand (Blodgett, Hill, \& Bakir, 2006).

\subsection{Objectives}

Customer complaint behavior (CCB) is defined as the action in which an individual provides negative feedback about the product or brand. CCB is adopted by the individual when he/she is not satisfied with the product or service. It includes evaluating the experience of consumers regarding the consumption of products and procuring positive or negative outcomes. However, there have been fewer researches in this segment and few facts are known about the complaining behavior of the consumers. We aimed to understand online consumer behavior by delineating the concept. To get better learning about online consumer behavior, we also focused on outlining the issues that are faced by con- 
sumers. An understanding of the major and minor needs and wants of the consumers was gained so that all the issues that were faced by the consumers could be resolved.

We aimed to contemplate online consumer behavior and its relationship with the online retail sector. It included discussing the history of the marketing along with recent changes in it. The concept of the marketing tools and improvements bought through it in the consumer service level were also discussed. The online retail segment is a highly competitive market in which several companies and retailers are working online to provide enriched customer services by using different marketing tools such as social media marketing, blogging, referral marketing, and others. The online retailer uses different online marketing tools to provide relevant information about the product and meet the expectations of the consumers.

We also outlined the role of new marketing strategies and simultaneously sketched the problems solved through these strategies. The facts related to the keys that the company needs to know about consumers during online retail were also discussed. Every retailer knows that the consumer is the main element of the entire marketing and selling process as most of the activities that are adopted by the retailers to sell products to the consumers. Therefore, to ensure that the consumers are provided with quality products and enriched services, online retailers adopt different marketing strategies. It helps in providing rightful product information to the consumers and increasing their trust in the company. It leads to the development of a strong and loyal customer base and increases the brand value of the company in the competitive market.

\section{Literature Review}

\subsection{Understanding Online Consumer Behavior}

The advancement in technology has led to the advent of modern means of shopping through digital means by making use of the internet. The online shopping platform includes the use of different e-commerce sites such as Amazon, Flipkart, Walmart, eBay, and Myntra for shopping through the internet. The increasing use of online shopping portals has changed consumer perception and behavior towards shopping. While focusing on customer behavior, it is referred to as the actions and attitude adopted by the individuals that pursue them to make product buying decisions. The online customer behavior is defined as the perception and attitude of the individuals towards making purchase decision when buying products through online portals (Koufaris, Kambil, \& LaBarbera, 2001).

Online retail has become an important part of the daily life of the consumers as it provides several advantages to individuals. It includes saving time of the consumers as the consumer buys products with a click-through online retail portals in place of visiting the near-by shops. Online shopping is also preferred by consumers as it saves energy, ensures $24 / 7$ availability, and eliminates waiting 
time. Online retailing also allows the consumers to purchase products from anywhere in the world by removing geographical limitations, allows comparison of price, and saves fuel (Jain, 2016). As a result, of the provision of several facilities such as easy payment, multiple choices, home delivery, cash against delivery, and easy returns, the use of online retailing sites has increased among the consumers. As per the survey conducted by eMarketer 2016, it was found that the value of e-commerce had reached 2.29 trillion US\$ and projected to reach 4 trillion US\$ by the end of the year 2020 (Rahman, Islam, Esha, Sultana, \& Chakravorty, 2018).

However, the consumer faced certain issues that were faced by consumers while performing online retailing activities. It includes issues related to fraud and security concerns. The consumers are at a high risk of fraud as they do not get the chance to inspect the merchandise before making a purchase. As a result, the consumer might receive a sub-standard product that is different from the product description mentioned in the online portal. Privacy is another major issue as many consumers are afraid of making online payments through net banking or credit cards owing to security issues. There is a lack of full cost discloser while making purchases through online retail stores which reduces the intend of the consumer to make the online purchase (Zuroni \& Goh, 2012).

There are options to compare the price of the product in different portals but the identification of the real cost of the product excluding additional charges such as tax and shipping is hard to find. It limits the use of online commerce sites among consumers when making cross-border purchases. Additionally, there are low instant satisfaction levels among consumers while making purchases through online retail stores. For example, when a product is purchased through a brick and mortar store, it allows the consumer to make instant use of the product. On the other hand, when a product is purchased through online stores, the consumer has to wait for 1 to 2 days for the delivery which diminishes the satisfaction level (Gong, Stump, \& Maddox, 2013).

To reduce the issue that is faced by consumers and meet their major/minor needs and wants, retailers must adopt a customer-centric approach. It includes focusing on three essential aspects of the consumers such as acquisition, retention, and development so that there is the maintenance of extended customer lifetime value. The retailing company must align its business process by fulfilling the needs and demands of customers so that there is a reduction in customer grievances. It includes establishing proper communication with the customers so that there is the attainment of product reviews and feedback. It will help in making improvements in the products and providing the consumer with high-quality products as per their expectations (Al-Debei, Akroush, \& Ashouri, 2015). Additionally, when the retailers provide quality services through their website and address risk perception issues associated with online shopping, there is a meeting of major/minor needs and wants of the consumers (Jarvenpaa \& Todd, 1997). 


\subsection{Contemplating on Online Consumer Behavior and Their Relationship with the Online Retail Sector}

To get a better understanding of online consumer behavior and their relationship with the online retail sector, it is essential to consider several external and internal factors. The external factors include cultural, social, and environmental aspects, while internal factors include psychological and personal aspects. The cultural factors include community class, sub-traditions, and cultural attributes while social factors include societal status, income, family unit, and reference attributes. The environmental factors include innovation, financial, and ecological attributes. Additionally, psychological aspects include inspiration, awareness, learning, conviction, outlook, self-concept, and individuality attributes, while personal aspects include age, the standard of living, profession, edification, and financial condition of the consumers (Ramya \& Ali, 2016).

In the online retailing sector, consumer behavior is also impacted by the association between the consumer and the online retail sector. Online consumer behavior is impacted by different factors such as ordering facilities, discounts, offers, and post-purchase service. Moreover, the recent spur in mobile technology has increased online purchasing attributes among individuals. As per the survey conducted by Ecommerce Europe, 2015, it was found that there has been a 14\% increase in the online business-to-consumer (B2C) sales. However, the increasing volumes of online retailing have created issues between the consumers and retailers in the form of non-delivery of products as per scheduled time (Nguyen, de Leeuw, \& Dullaert, 2018). On the other hand, due to increased online retailing volumes, the company faces issues related to fulfilling of the online orders on time, meeting last-mile delivery targets on time, administering inventory, and warehouse management (Fernie \& McKinnon, 2009). The issues that are faced by the customers while making online purchases impact their online consumer behavior and their relationship with the online retail sector (Agatz et al., 2008).

The studies by scholars and researchers suggest that there is a difference in the buying perception of consumers while making purchases through online segments and physical stores. In online shopping, the retailer and shopper are separated in terms of time and space while in the case of a physical store, the retailer presents the merchandise to the consumers. As a result, the needs and wants of the customers while making purchases through the online store and physical stores get differentiated. For example, there is a difference in duration of interaction, information provision, and brand presentation. In the physical store, the consumer establishes more interaction with the seller asking about the product details, quality, brand, and make. The customer also enquires about the return policy and their previous buying experience. However, all these facilities are not available to the customers that are making online purchases as they cannot connect to the retailer directly and have to communicate through the company portal or customer care representatives. The online customer could not enquire about the product quality from the retailers and have to depend upon 
the customer reviews provided by the users. As a result, the lack of direct interaction of the consumers with the retailers, ambiguity about the quality of the product, mixed customer reviews create differences between the online consumer behavior and their relationship with the online retail sector (Grewal et al., 2004).

The online customer behavior is also impacted by the services and facilities that are provided by online retailers. It includes providing services related to last-mile delivery, merchandise collection, catalog administration, and return management. If the online retailer provides several merchandise collection options, the consumers can select from a large variety of products to match his/her tastes and preferences. It creates a positive impact on the purchase decision and perception of the customers towards the online retailing segment. On the other hand, if the online retailer does not provide several merchandise collection options, the consumer will have a limited large variety of products to select and match his/her tastes and preferences. It creates a negative impact on the purchase decision and perception of the customers towards the online retailing segment (Brynjolfsson et al., 2011). The consumer attitude towards online retail shopping is also influenced by trust and perceived benefits associated with the products. The other factors such as website design, quality of merchandise, information quality on the online retail website, payment systems, delivery aspects, and security attribute also impact the association between the online consumer and retailer (Haque et al., 2015).

Marketing and promotion of products by online retailers also play an important role in determining the online consumer behavior and their relationship with the online retail sector. While focusing on digital marketing, it is an advertising procedure in which electronic means and interactive technologies are used to establish an association between the retailers and consumers (Minculete \& Olar, 2018). The online retailers use different digital marketing techniques such as email marketing, social media marketing, content marketing, search engine optimization, and pay per click marketing to attract the online consumers. For example, search engine optimization is increasingly used increasing the ranking of the products and company in the search engines such as Google Search and Yahoo.

The use of digital marketing helps online retailers to establish interaction with consumers through websites, social media sites, mobile applications, emails, direct calls, and messages. The online retail sites also provide chatbot services to the customers so that any issue faced by them is resolved by the customer assisted device. For example, Amazon which is one of the topmost online retail companies Amazon uses social media sites such as Facebook, Twitter, and Instagram to promote its products, increase its market presence, and augment visitor strength. As a result, the company provides efficient platforms to the consumers to avail of rightful information about the product, interact with the online retailers, and make product buying decisions. Thus, when constructive 
initiatives such as developing communication channels, accurate product specification, customer reviews, and on-time delivery are provided by online retailers, there is the development of a positive relationship between the online customer and online retailers.

\subsection{Comprehending on the Use of Marketing Tools to Improve Consumer Service Levels}

The concept of marketing originated in ancient times when the commerce of goods and products took place a thousand years ago. During ancient times, the marketing of products was done through paintings on walls, billboards, door-to-door selling, and distributing pamphlets. However, with the Industrial Revolution, the traditional marketing techniques adopted by the retailers changed and gave way to modern marketing techniques. It includes using print advertising in the year 1450 in the form of brochures and fliers (Semiryad \& Voskoboinikov, 2020).

In the 1730s, the retailers used magazines as an effective source of advertisement while in the year 1839 and 1867 posters and billboards became important sources of marketing. Then, the revolution of radio advertising came in the year 1922 which was followed by television marketing in 1941 (Buchwitz, 2018). Telemarketing took place in 1950 which was advanced by mobile campaigning and marketing with the discovery of the internet. Thus, the years from 1970 to 1994 witnessed significant growth in the digital marketing segment with the emergence of e-commerce platforms and database marketing. The other major inventions such as search marketing, blogging, pay per click, social media marketing, and Google analytics took place in the subsequent years.

Marketing plays an important role in promoting the products and services of a company to larger audiences. It is regarded as a vital contributor to increasing the sales and profitability of the company. Marketing also allows the company to gain learning about customer perception and helps in fulfilling the needs and wants of the customers. It also acts as an efficient medium to transmit and ensure movement of the merchandise which creates an association between different intermediaries such as retailers, manufacturers, suppliers, and dealers. Marketing ensures that there is the availability of essential goods and services to the customers at an affordable price. It is also known to be an essential employment generator that provides earning opportunities to several individuals (Bala \& Verma, 2018).

Marketing is also regarded as the basis of making the product buying decision to consumers. For example, when the product is advertised by famous movie stars or celebrities, the consumers tend to buy products endorsed by their favorite celebrities. Moreover, marketing also acts as a source of new ideas as its tools and techniques keep on changing with the advancement in technology and passage of time. Thus, marketing highly contributes to the economic well-being of the country and raises the living standard of the community. 
However, with the modernization and introduction of new marketing tools, the traditional forms of marketing have changed and replaced with new-age marketing tools to improve consumer service levels. It includes the use of digital means of marketing such as social media, referral marketing, and visual marketing so that customer interaction is increased with online retailers. Social media marketing has become an efficient tool to market the company products by campaigning company products in different networking platforms such as Facebook, Instagram, YouTube, and Twitter (Vinerean, 2017).

The social media sites use attractive content, images, videos, and audios to attract the attention of the customers. To improve the consumer service level, the online ensures that the content that is shared on the social media platform is useful and authentic. It also includes increasing the engagement levels of consumers by organizing contests or campaigns. As a result, when the consumers experience good social experience, they recommend the brand to the other. It not only increases the customer satisfaction levels but also increases the scalability of the company (Krizanova, Lăzăroiu, Gajanova, Kliestikova, Nadanyiova, \& Moravcikova, 2019).

Referral marketing is another marketing tool that is related to the word of mouth advertisement of the product and brand. As per the survey conducted by Nielsen's latest Trust In Advertising report, it was found that $84 \%$ of consumers highly prefer to buy merchandise as suggested by the family members, friends, and close associates. When the retailers provide adequate services to the customers in the form of quality products, on-time delivery, hassle-free returns, competitive price, and post-sales services, the consumers become loyal advocates of the company and refer the company and product to other individuals. However, to gain the advantage of the referral, the marketer and retailer need to ensure that the customers are provided enriched customer experience and ask for referrals politely to their friends. This marketing technique ensures that all the grievances of the customers are met by providing high-quality services (Berman, 2016).

While performing online shopping activities, the customer face issues related to lack of rightful information as they could not establish interaction with the manufacturers or producers. As a result, online shoppers have to depend upon the reviews that are provided by the other users to decide on the purchase of merchandise. However, this issue faced by the customers is resolved by marketers by introducing blogging and microblogging platforms to the customers. Through the blogging platform, the consumers can avail of all the information about the product which they intend to buy. In the current age of digital revolution, each manufacturer and retailer have their websites and blogging sites that provide rightful information about the product to the consumers. Additionally, there are options available to the customers that they can more information to the blog, comment on it, ask for any query, or object to the content if not appropriate. It increases the engagement level of the customers with the company 
and provides ample opportunities to address customer's queries.

Incorporating visual marketing techniques such as providing information through images, photos, videos, and infographics so that it is feasible for all the consumers to acquire learning about products and services provided by online retailers. As per the survey conducted by Skyword, it was found that the readability or viewership of the article or blog increased by $94 \%$ if it contained images in it. The use of images in the blogs and articles help the customer to understand the meaning and message of the content easily. As a result, the customers that do not have a high fluency in the English language are also able to understand the content of the article or blog (Venkatraman, 2020).

Moreover, marketers are also advertising their products to customers in different regional languages such as Hindi, Marathi, Bengali, and Tamil. According to the survey conducted by KPMG India \& Google, 2018, it was predicted that there would be 201 million Hindi base users (38\%), 51 million Marathi base users (9\%), 42 million Bengali base users (8\%), and 32 million Tamil users (6\%) against 200 million English users in India by the year 2021. Therefore, marketers are efficiently capturing this opportunity and promoting products in different languages through Hindi posts so that there is a generation of huge traffic on the website. It helps online retailers to reach consumers belonging to different communities and promote products to large masses. It also helps in addressing the issues that are faced by the non-English consumers and meet the needs and want of all consumers that use online shopping platform effectively.

Another major marketing tool that can be used by marketers to improve consumer service levels is giving free trials to the customers. It includes giving promotional sales rewards, gifts, offers, and discounts to customers. The offering of free stuff to the customers helps in establishing close associations with the customers. It also includes giving free stuff to the bloggers and podcasters that promote to product digitally and have huge fan followings. In return for the free stuff received, the podcasters will promote the product socially on digital platforms. As a result, by using the giving free trial method of promotion, an increasing number of customers get associated with the company and become loyal consumers for a long duration.

Affiliate marketing is another technique that is used by marketers to broaden the audience market and boost brand reputation. It is an efficient method of scaling sales and traffic to the website by including consumers as marketers. It is known as the most cost-effective form of digital marketing wherein the advertisers are only paying for the converted leads without bearing any overhead cost related overall marketing campaign. Affiliate marketing allows the consumers to become ambassadors of the product and promote the product to their associates and get rewards in return upon conversion. Thus, this marketing tool increases the participation of consumers in the company marketing process that enhances customer experience and value. It also provides opportunities for the customers to share their views regarding product improvement so that the value of the 
product could be increased. Thus, it can be said that different marketing tools such as referral marketing, affiliate marketing, visual marketing, blogging, and social media marketing to improve consumer service levels (Olbrich, Schultz, \& Bormann, 2019).

\subsection{Outlining the Role of New Marketing Strategies}

There are different types of issues that are faced by the consumer while making online purchases such as returns, refunds, shipping errors, billing errors, wrong information, and unordered merchandise. To resolve the issues faced by the consumers, different marketing strategies such as interactive marketing strategy and digital marketing strategy are adopted by online retailers. While focusing on the interactive marketing strategy, it includes adopting marketing processes that encourage the active engagement of consumers with the marketing campaign of the company. It promotes the adoption of the customer-centric approach in the business processes. It specifies that all activities of the organization must be carried out by keeping the customer service aspects into consideration (Nizam, Jaafar, \& Supaat, 2018).

Consumers appreciate the initiatives taken by the company to include them in the company working process. For example, when the consumers log into the company website, they might want to see their name with the merchandise interests and communication predilections. When such personalized services are provided to the consumers, they become highly satisfied and tend to remain associated with the company long-term. It also develops a positive relationship between the consumer and brand which empowers the consumers to share product reviews and provide updates about the product response in the market. The consumers also share their grievances with the product and recommend measures that would improve product quality and allow the company to provide better services. For example, Amazon develops a constructive association with its consumers by addressing their grievances in the earnest. It helps in regaining the trust of the consumers and reducing the chances of CCB against the company or products (Majid, 2020).

Another marketing strategy that can be used by the consumers is saving consumer data and proposing products to them as per the identified pattern. The digital platform is an eminent sector that includes the use of different technologies and advancements. Through the innovative tools, the marketers can save the customer search data and other product purchase details. Thus, by acquiring and analyzing the customer tastes and preferences based on past searchers and shopping behavior, the online retail company suggests products to the customers. As a result, the time is taken to make online searches get reduced and high satisfaction levels are experienced by the consumer. Moreover, online retailers also ask consumers to provide their feedback regarding their experience with the product and site. It helps the company to bring improvements in the online retail portal and product quality so that the entire online shopping experience of the con- 
sumer is enhanced (Payne, Peltier, \& Barger, 2017).

Digital marketing is another strategy that can be adopted by the online retailers to promote products, establish communication with the consumers, and resolve the issues that are faced by the consumers. The digital marketing strategy includes two essential aspects that are pulled and push concepts. The digital push aspect is associated with a company perspective in which association is established with the consumers by using different technologies. It includes using email, instant messaging, banner marketing, podcasting, blogs, content marketing, and video marketing. The company provides rightful information about the products which makes it easy for the online consumer to form product purchase decisions. On the other hand, the pull aspects include the consumer perspective that is when they try to connect with the company. The consumer can connect with the company by posting their comments on the company website, social media sites, blogs, instant messages, or calls. The consumers may also signup with the official text message, newsletter, podcasts, and email to share their grievances or issues with the product (Kingsnorth, 2019).

By developing digital communication with the consumers, the company can get a better understanding of the issues that are faced by the users. It includes interacting through private messages, customer care, and the grievance department of the company. When the company representative listens to consumer issues and resolves them, it develops a trust-based association between them. Additionally, many a time, the consumers are faced with issues such as complicated websites as the site navigates then to different options and irrelevant details. It reduces the interest of the visitors to explore the products provided by the online retailer and they switch to less complicated websites. Thus, the online retailers must ensure that the websites made for consumer interface are simple, attractive, and informative so that more consumers visit the website (Mandal \& Joshi, 2017).

The consumers also often get bored by visiting the same sites again and again and tend to switch to new dealers to gain newer experiences. Therefore, online retailers must introduce engaging activities within the website in the form of gamification, social shopping, and interactive product guides so that the involvement of the consumer increases with the company. For example, Bonobos launched the Easter egg hunt contest to increase consumer participation. The first 50 consumers that won the competition were awarded $\$ 25$ to $\$ 100$ credit. The contest certainly increased the involvement of the consumers to the websites and provided benefits to the company in terms of sales.

Another major issue faced by online shoppers is limitations with touching or feeling the product. It is resolved by marketers by providing rightful information about each aspect of the product in terms of size, color, and other specifications. For example, fashion company ASOS provides a unique consumer experience by displaying catwalk videos of the apparel so that the consumers get an idea about the cut and fit of the attire. It would help them to make a better online product 
buying decision. The other issues related to wrong billing or tracking of the order are also addressed by the marketers by supporting the customer in tracking the product through logistics management. Thus, it can be said that different marketing strategies such as interactive marketing and digital marketing are adopted by the online retailers to attract customers and resolve the issues that are faced by them while/after making online purchases.

\section{Findings and Discussion}

In the current era, with the advancements of technology, the consumers are provided with several shopping options such as brick \& mortar and online shopping portals. Due to increased facilities such as saving time, energy, fuel, and convenience provided by the online retail sector, consumers increasingly prefer to use online retail sites to purchase merchandise. However, at times, the consumers face certain issues while making online purchases such as wrong information, late delivery, poor return policy, and improper billing. It reduces the satisfaction level of the consumer while making online purchases. Thus, a dissatisfied individual adopts Consumer's Complaining Behaviour (CCB) and complaints about the product to the company. The consumer may make a private or public complaint to the company and ask to resolve the issue by replacing the product or mending it. $\mathrm{CCB}$ also negatively impacts the image of the company and reduces the trust between the consumer and the brand. Therefore, different marketing strategies and tools such as social media marketing, blogs, content marketing are adopted by online retailers so that communication is established with the consumers. By developing interactive platforms, the consumers can directly connect with the company and share their grievances and feedback with them. It will help the company to get understanding the needs and wants of the consumers and modify the product or service accordingly. It will not only improve the quality of the product but also help to rebuild the trust with the consumers. As a result, with the provision of quality products to the consumers, there will be a reduction in complaints by the consumers and the online retail company will regain its lost repute in the market.

\section{Conclusion}

Online retailing is an innovative platform that includes modifications as per the needs and demands of the consumers. The buying decision in online shopping is made entirely on the product information shared by the online retailer and facts available through different marketing sites of the company in the form of blogs, videos, and content. We aimed to sketch the details of the online consumer behavior so that better understanding is gained about the issues that are faced by consumers while making online purchases. The major limitation of online shopping is the lack of touch and feel or the product and making payments without interacting with the dealers. Therefore, online retailers must provide rightful information to consumers through their websites, blogs, podcasts, and videos so 
that it is easy for online shoppers to make online purchase decisions. We also discussed different marketing tools such as affiliate marketing, referral marketing, blogs, and social media marketing that are used by online retailers to improve consumer service levels. The use of different marketing tools certainly provides rightful information to online consumers, improves their online purchase decision making, and reduces the incidence of complaints.

\section{Limitations and Future Scope}

This research is limited to online complaints and third-party complaints such as word-of-mouth or bad-mouthing that occurs in Internet chat rooms. Also it is limited as it lacks in touch and feel and also makes payments without interacting with the sellers. Future research is using various other marketing tools to provide information to consumers in order to improve their buying experience and decision and also helps in reducing complaints, Also, future studies could delve deeper into the role of emotions and other personality traits of interest to consumer behaviorists and psychologists, such as pride, aggression, and shyness, on complaint channel selection. Finally, cross-cultural differences in personality traits such as shame a proneness warrant can be considered for future research.

\section{Conflicts of Interest}

The author declares no conflicts of interest regarding the publication of this paper.

\section{References}

Agatz, N. A., Fleischmann, M., \& Van Nunen, J. A. (2008). E-Fulfillment and Multi-Channel Distribution: A Review. European Journal of Operational Research, 187, 339-356. https://doi.org/10.1016/j.ejor.2007.04.024

Al-Debei, M. M., Akroush, M. N., \& Ashouri, M. I. (2015). Consumer Attitudes Towards Online Shopping: The Effects of Trust, Perceived Benefits, and Perceived Web Quality. Internet Research, 25, 707-733. https://doi.org/10.1108/IntR-05-2014-0146

Alqahtani, M. (2011) Officers Do Not Know That There Are Rights and Responsibilities to Be Considered.

Bala, M., \& Verma, D. (2018). A Critical Review of Digital Marketing. International Journal of Management, IT \& Engineering, 8, 321-339.

Berman, B. (2016). Referral Marketing: Harnessing the Power of Your Customers. Business Horizons, 59, 19-28. https://doi.org/10.1016/j.bushor.2015.08.001

Blodgett, J., Hill, D., \& Bakir, A. (2006). Cross-Cultural Complaining Behavior? An Alternative Explanation. Journal of Consumer Satisfaction, Dissatisfaction and Complaining Behavior, 19, 103-117.

Brynjolfsson, E., Hu, Y., \& Simester, D. (2011). Goodbye Pareto Principle, Hello Long Tail: The Effect of Search Costs on the Concentration of Product Sales. Management Science, 57, 1373-1386. https://doi.org/10.1287/mnsc.1110.1371

Buchwitz, L. A. (2018). A Model of Periodization of Radio and Internet Advertising History. Journal of Historical Research in Marketing, 10, 130-150.

https://doi.org/10.1108/JHRM-09-2016-0020 
Fernie, J., \& McKinnon, A. (2009). The Development of Retail Logistics. In J. Fernie, \& L. Sparks (Eds.), Logistics and Retail Management, Emerging Issues and New Challenges in the Retail Supply Chain (pp. 207-232). London: Kogan Page.

Gong, W., Stump, R. L., \& Maddox, L. M. (2013). Factors Influencing Consumers' Online Shopping in China. Journal of Asia Business Studies, 7, 214-230. https://doi.org/10.1108/JABS-02-2013-0006

Grewal, D., Iyer, G. R., \& Levy, M. (2004). Internet Retailing: Enablers, Limiters and Market Consequences. Journal of Business Research, 57, 703-713. https://doi.org/10.1016/S0148-2963(02)00348-X

Haque, A., Anwar, N., Yasmin, F., Sarwar, A., Ibrahim, Z., \& Momen, A. (2015). Purchase Intention of Foreign Products: A Study on the Bangladeshi Consumer Perspective. SAGE Open, 5. https://doi.org/10.1177/2158244015592680

Jain, A. S. (2016). Top 10 Benefits of Online Shopping That Make Your Life Easy. https://toughnickel.com/frugal-living/Online-shopping-sites-benefits

Jarvenpaa, S. L., \& Todd, P. A. (1997). Consumer Reactions to Electronic Shopping on the World Wide Web. International Journal of Electronic Commerce, 1, 59-88. https://doi.org/10.1080/10864415.1996.11518283

Kingsnorth, S. (2019). Digital Marketing Strategy: An Integrated Approach to Online Marketing. London: Kogan Page Publishers.

Koufaris, M., Kambil, A., \& LaBarbera, P. A. (2001). Consumer Behavior in Web-Based Commerce: An Empirical Study. International Journal of Electronic Commerce, 6, 115-138. https://doi.org/10.1080/10864415.2001.11044233

Krizanova, A., Lăzăroiu, G., Gajanova, L., Kliestikova, J., Nadanyiova, M., \& Moravcikova, D. (2019). The Effectiveness of Marketing Communication and the Importance of Its Evaluation in an Online Environment. Sustainability, 11, 7016.

https://doi.org/10.3390/su11247016

Majid, K. A. (2020). Effect of Interactive Marketing Channels on Service Customer Acquisition. Journal of Services Marketing. https://doi.org/10.1108/JSM-08-2019-0282

Mandal, P., \& Joshi, N. (2017). Understanding Digital Marketing Strategy. International Journal of Scientific Research and Management, 5, 5428-5431.

Meng, F., Wang, S., Peters, S., \& Lawson, G. W. (2010) A Glimpse into the Consumer Complaining Behavior of Immigrants. Journal of Consumer Satisfaction, Dissatisfaction and Complaining Behavior, 23, 111-136.

Minculete, G., \& Olar, P. (2018). Approaches to the Modern Concept of Digital Marketing. International Conference Knowledge-Based Organization, 24, 63-69. https://doi.org/10.1515/kbo-2018-0067

Nguyen, D. H., de Leeuw, S., \& Dullaert, W. E. (2018). Consumer Behaviour and Order Fulfilment in Online Retailing: A Systematic Review. International Journal of Management Reviews, 20, 255-276. https://doi.org/10.1111/ijmr.12129

Nizam, N. Z., Jaafar, J. A., \& Supaat, S. H. (2018). Interactive Online Advertising: The Effectiveness of Marketing Strategy towards Customers Purchase Decision. In MATEC Web of Conferences (Vol. 150, p. 05043). Les Ulis: EDP Sciences. https://doi.org/10.1051/matecconf/201815005043

Olbrich, R., Schultz, C. D., \& Bormann, P. M. (2019). The Effect of Social Media and Advertising Activities on Affiliate Marketing. International Journal of Internet Marketing and Advertising, 13, 47-72. https://doi.org/10.1504/IJIMA.2019.097896

Payne, E. M., Peltier, J. W., \& Barger, V. A. (2017). Omni-Channel Marketing, Integrated 
Marketing Communications and Consumer Engagement. Journal of Research in Interactive Marketing, 11, 185-197. https://doi.org/10.1108/JRIM-08-2016-0091

Phau, I. Y., \& Sari, R. P. (2004). Engaging in Complaint Behavior: An Indonesian Perspective. Marketing Intelligence and Planning, 22, 407-426. https://doi.org/10.1108/02634500410542770

Rahman, M. A., Islam, M. A., Esha, B. H., Sultana, N., \& Chakravorty, S. (2018). Consumer Buying Behavior towards Online Shopping: An Empirical Study on Dhaka City, Bangladesh. Cogent Business \& Management, 5, Article 1514940. https://doi.org/10.1080/23311975.2018.1514940

Ramya, N., \& Ali, M. (2016). Factors Affecting Buying Behavior. International Journal of Applied Research, 2, 76-80.

Semiryad, N. Y., \& Voskoboinikov, S. G. (2020). Brief History of Advertising from Antiquity till Nowadays. In Будущее Науки-2020 (pp. 13-16).

Singh, J. (1990). Voice, Exit, and Negative Word-of-Mouth Behaviors: An Investigation across Three Service Categories. Journal of the Academy of Marketing Science, 18, 1-15. https://doi.org/10.1007/BF02729758

Tronvoll, B. (2007). Customer Complaint Behaviour from the Perspective of the Service-Dominant Logic of Marketing. Managing Service Quality: An International Journal, 17, 601-620. https://doi.org/10.1108/09604520710834966

Venkatraman, S. (2020). The Value of Visual Marketing as a Tool to Gain Consumer Interest. 2020 Internship: Final Reports.

Vinerean, S. (2017). Importance of Strategic Social Media Marketing. Expert Journal of Marketing, 5, 28-35.

Zuroni, M. J., \& Goh, H. L. (2012). Factors Influencing Consumers' Attitudes towards E-Commerce Purchases through Online Shopping. International Journal of Humanities and Social Science, 2, 223-230. 